\title{
THE ESTABLISHMENT OF ULTRA-ORTHODOXY IN MANCHESTER
}

\section{Z. Yaakov Wise*}

Abstract: This paper examines the social, political and cultural milieu in which the Machzikei Hadass (Upholders of the Faith), the principal ultra-orthodox community in Greater Manchester was founded in the mid 1920s. Like its counterparts in late nineteenth century Eastern Europe, $M H$ (as it is always known) was a reaction to a perceived slide from strict, 'Torah true' orthodoxy. In this case what they saw as a hybrid of modern orthodoxy and worse; genteel Anglo-Jewish compromise. The hard core of MH founders were hassidim of the Rebbes of Belz, Galicia and mostly related both by geographic origin and by kinship. This tightly knit group of (to quote Prime Minister Harold Wilson) 'politically motivated men,' waged a thirty years war against the Manchester Jewish establishment and emerged triumphant. Their descendents now represent over one quarter of all the Jews in Greater Manchester and will form a majority by the middle of the present century.

\section{Introduction}

In late Victorian Manchester, the Jewish communities of the early and mid-nineteenth century were gradually sliding into middle class respectability. In adopting London's Bayswater Synagogue liturgy, the South Manchester Synagogue had set the predominant style of suburban orthodoxy in a 'gentle reform' of ritual, acceptable equally to the chief rabbi and to a self-conscious middle-class. It was a style which later recommended itself, in various forms, to the other suburban groups in north as well as south Manchester, which wished to express the degree of their acculturation to English middle class norms without entertaining the extreme of Reform. In its origin, it made the point that a 'suburban synagogue' was not one simply which met the needs of well-to-do Jewish families which had colonised a new district; the crucial matter was sense of corporate class identity which was expressed not only in topographic terms. ${ }^{1}$

There were however small groups of hassidim and other strictly observant Jews who came together in the summer of 1925 to found a resistance movement to this slide towards acculturation and, in their view, assimilation. This struggle to start a new

\footnotetext{
Hon. Research Fellow, Centre for Jewish Studies, University of Manchester. Email: yaakovwise@aol.com

${ }^{1}$ B. Williams, The Making of Manchester Jewry 1740-1875 (Manchester: Manchester University Press, 1976), 325.
} 
ultra-orthodox organisation in the mid 1920s was not without precedents. There had been small minorities of orthodox Jews in Manchester who had resisted the lure of acculturation and acceptance. One of the first indications of such individuals living in Manchester is a letter from the famous hassidic rebbe, Zadok HaKohein of Lublin to a friend, a 'Reb Osher' who was practising as a physician in Manchester in 1864. Reb Zadok urges his friend to leave the city 'so bereft of Judaism' and move to the Land of Israel. ${ }^{2}$ The earliest local evidence of new, more orthodox forces was probably in the movement that began in 1875 for the creation of a study centre, the Manchester Beth Hamedrash 'where the Holy Law can be studied and expounded and where the rising generation may obtain a thorough knowledge of Hebrew.' The movement was promoted by influential, but observant immigrants such as the optician William Aronsberg who viewed: 'with alarm and horror the ungodly way in which [young men] are allowed to grow up, deficient in religious feeling and indulging in immoral employment; and who, to remedy this awful state of things, are endeavouring to provide an antidote to the billiard rooms and card tables on which the young men spent their leisure moments, Sabbaths and Festivals. ${ }^{3}$ The movement failed, perhaps because the immigrant middle class then lacked political experience, but it was the beginning of a process of immigrant self-assertion.

Later a brief attempt was made to establish a local halakhic authority acceptable to the immigrants with the appointment in 1893 of Rabbi Abba Reiness (or Abba ReinesCohen as he is called in later Manchester Shechita Board (MSB) minutes) of Kovno (Kanaus, Lithuania) as Moreh Haro'oh (Communal Judge or Dayan) to the Polish and Russian Jews of Hightown and Strangeways. 'A letter was read from [Chief Rabbi] Dr Adler dated 7 September [1893] addressed to the Broder Synagogue stating that the Rev Abba Reiness was competent to be appointed to pasken shaalos [answer questions in rabbinic law] and to act as a preacher. ${ }^{4}$ Herman Adler, for once showing some foresight and empathy, had thus endorsed the appointment. However, Reiness was also rabbi of the Strangeways Synagogue, and the other hevra leaders, jealous of their independence and fearing an Adlerian plot, ensured the experiment was short-

\footnotetext{
${ }^{2}$ L. Reich, 'Chassidim in Manchester', notes prepared for the chapter 'Manchester' in H. Rabinowitz, A World Apart: The Story of the Chasidim in Britain (London: Vallentine Mitchell, 1997). Permission granted.

${ }_{3}^{3}$ Quoted in Williams, The Making of Manchester Jewry 1740-1875, 332.

${ }^{4}$ Manchester Shechita Board (MSB) minutes, 10 December 1893, in the possession of the author.
} 
lived. ${ }^{5}$ Reiness later joined the newly developing Shechita Board as one of its parttime 'reverend supervisors,' the rabbis involved with the board not receiving the more appropriate title of 'dayan' until well into the 20th century.

There had been individuals and small hevros who had tried, almost always unsuccessfully, to maintain the religious standards of 'der alter heim' - their towns and villages of origin in eastern and central Europe. One of the earliest in Manchester was the Hevras (later Beis HaKnesses) Anshei Krakow or Cracow Hebrew Society founded in January 1868 with the objectives of 'holding divine service on the Sabbaths and festivals, relief of members during the week of mourning, providing a minyan at a house of mourning \&c. ${ }^{6}$ Most of these families and groups remained heimish, traditionally observant, only during the lifetime of the original immigrants. Many of them and their children, born into piety and poverty in the grimy, malodorous surroundings of Red Bank, Strangeways and Lower Broughton were soon anglicised by a Manchester Jewish establishment and its institutions eager to slough off the community's label of 'alien' and become socially acceptable to middle class, gentile society. According to Williams the Jewish rich also saw themselves duty bound to improve the lives of their co-religionists just as the liberal gentiles improved the life of the city's gentile poor. The upper and middle classes bore a moral responsibility for their workers and for the unemployed. ${ }^{7}$

In the late nineteenth and early twentieth century many of the original orthodox hevros had evolved into fully-fledged Manchester synagogues under the influence and patronage of the chief rabbinate and the BoD. The Lubavitch shteibl (small synagogue), founded in 1896, was almost the only harēdi synagogue that had survived with its hassidus intact for more than the first immigrant generation. Unlike east London where Sir Samuel Montague, MP had successfully organised the local hevros into the Federation of Synagogues, the Manchester immigrants had no wealthy, modern orthodox, politically astute patron who could meet and occasionally defeat the establishment on it own turf. Indeed Montague had visited Manchester in the mid

\footnotetext{
${ }^{5}$ L. Gartner, The Jewish Immigrant in England 1870-1914 (London: Allen and Unwin, 1960), 215.

${ }^{6}$ Manchester entry in A. Myers, The Jewish Directory for 1874 (London: Philip Valentine, 1874), 76.

${ }^{7}$ See Williams, The Making of Manchester Jewry 1740-1875, 89. Of course this also complies with the important Biblical mitzvos of charity and love of one's neighbour.
} 
1890 s and mooted such a project but without success. ${ }^{8}$ As the second generation, the Manchester born children who moved up Cheetham Hill Road from the slums of Red Bank matured, nearly all saw undiluted orthodoxy only as an impediment to their progress and acceptance into middle class 'polite' society.

This rapid acculturation of late nineteenth and early twentieth century Manchester Jews was far from unique. The same phenomenon could be observed in London, Leeds, Liverpool, Glasgow, New York, Chicago, Buenos Aires and even Jaffa-Tel Aviv. In the cities of Germany and Austro-Hungary this decline in undiluted orthodoxy had started two generations earlier and by the Great War was complete. Only the few and relatively small austritt gemeinde communities in cities such as Leipzig and Frankfurt-am-Main could one find the remains of a once flourishing German strict orthodoxy. Nevertheless, a few of these remnants from Germany would combine with the Brody hassidim to create a new major institution within the increasingly fractious orthodoxy of Manchester Jewry.

There were still small vestiges of their original immigrant hassidus in several of the early 20th century Manchester synagogues. By the time the Broder Synagogue (later renamed the North Manchester and anglicised) was founded in the late 1890s there were enough members from hassidic families to influence the liturgy so that Hallel was said after Maariv on the first night of Pesakh and L'Dovid Mizmor at Maariv on Rosh Hashona. ${ }^{9}$ The Oestrricher (Austrian) Synagogue adopted the full nusakh Sephard (hassidic liturgy) on its foundation as eventually did the Polish Synagogue. The Romanian Synagogue founded in Strangeways in 1889 for Jews from South East Europe included a number of hassidic families from Vizhnitz and it also adopted nusakh Sephard. In 1896 the first Lubavitch shteibl was founded near Victoria Station above a provender's shop and became famous as the 'Hayshop Shul'. Lubavitch use a slightly different liturgy to other hassidim, edited by the Baal HaTanya, author of the core hassidic text Tanya, Shneor Zalman of Liadi, from the writings of the Safed kabbalist Yitzhok Luria and known in his honour as 'nusakh Ari.'10

\footnotetext{
${ }^{8}$ Private conversation with the historian Bill Williams.

${ }^{9}$ These are not said in standard Ashkenazi liturgy synagogues.

${ }^{10}$ The full name of the oldest surviving Lubavitch synagogue in Manchester is Adass Yisroel Nusakh Ari.
} 
Whilst most of the members of these synagogues may have come from hassidic backgrounds, in practice many of them confined their difference from other Manchester Jews to the synagogue service and a few customs in the home. By the early twentieth century few Manchester Jews had full beards, ${ }^{11}$ almost none wore hassidic garb other than perhaps a gartel, the long cord belt worn during prayer to separate the lower 'animal' half of the body from the upper 'spiritual' part. The first local hassid to act as a full rebbe and wear full hassidic garb publicly was Zusya Golditch (father of Dayan Isaac Golditch, minister of the Austrian shul and a member of the Manchester Beth Din) who arrived in Manchester about 1919 having previously lived in Antwerp and Leeds. A commanding and imposing figure, he originally lived off Camp Street, Higher Broughton but later was one of the first harēdim to move north into the more affluent suburb of Broughton Park. ${ }^{12}$ Zusya Golditch operated as a classic hassidic rebbe, running a minyan in his home and giving regular Talmud classes and hassidic gatherings for storytelling and refreshment. Golditch's activities over several decades are briefly recorded in the appointment diaries of one of his 'hassidim,' Yosef Chaim (Joseph Charles) Sufrin who later became one of the leaders of the second generation, Manchester born, harēdim. ${ }^{13}$

The 1905 Aliens Act, the first legislation solely aimed at restricting immigration to Britain, was principally directed at regulating the flow of Russian and Polish Jews into England. Whilst the law was honoured more in breach than in observance, its message was not lost on the aspiring social climbers of Jewish Manchester. In addition, the six-day working week was an almost insuperable test that tore many Manchester born children from the strict orthodoxy of their parents and indeed sometimes tore the parents themselves. Observance of the Sabbath is one of the cardinal laws and principles of Judaism. In addition to its direct Biblical status as one of the ten Statements of Judaism - the Decalogue, ${ }^{14}$ Sabbath observance has always

\footnotetext{
${ }^{11}$ Ironically one of the few was the father of MSB president Reuben Barrow-Sicree, the principal preWW2 opponent of MH.

${ }^{12}$ Tapes of an interview with Dayan I Golditch, Oral Archive at Manchester Jewish Museum, May/June 1978.

${ }^{13}$ J.C. Sufrin, Appointment Diaries of Yosef Chaim Sufrin of Manchester (1902-1985) for the years 1914-1985, private collection in the possession of his children.

${ }^{14}$ Usually mistranslated as the 'Ten Commandments.' There are, in fact, 613 Biblical commandments.
} 
been a test of an individual's belief in and loyalty to the Creator G-d and his Torah. To perform creative labour on the Sabbath by working in textiles, leather or cigarettes on Saturdays is to perform a serious desecration of the divinely given world order. Thus those who attended the Manchester 'market' or 'workers' minyans,' early morning Shabbos services held to enable immigrants to both pray and get to work on time, appeared to signify to their children that economic survival for the poor and economic success for the better off was preferable to strict Jewish belief and practice. Inevitably a decline in Sabbath observance often preceded a general decline in orthodox lifestyle and commitment especially in the second generation.

However, there was a small minority of English born children who followed the example of their migrant parents and followed a strictly orthodox lifestyle whatever the restrictions it might place on their economic advancement. Several of these were the sons of Isadore (Yitzhok) Sufrin of Jassy (Iasi, Romania) who had migrated to Manchester in 1899. The eldest, Yosef Chaim (Joseph Charles), born in Manchester in 1902, kept an appointment diary from the age of twelve in which he records his daily schedule including the synagogues in which he prayed; the daily shiurim (Torah classes) he attended and the orthodox youth and political groups of which he was a leading member.

Sufrin worked for his father in the family linen drapers business in Higher Broughton before qualifying as an optician and later running a soap manufacturing business. Yosef Chaim and his brother Leonti (Aryeh Leib) became leaders of the Aguda's Sinai youth movement in their early teens and progressed to the adult organisation in their early twenties. ${ }^{15}$ Yosef Chaim was elected Chairman of the Manchester branch of the Aguda at a meeting in the Polish Synagogue in January 1930 at the relatively young age of twenty-seven indicating the importance the local movement placed on encouraging English born 'second generation' men to take up communal and political

${ }^{15}$ Jewish Chronicle, 8 August 1919, 19. 
activities. ${ }^{16}$ His brother Leonti worked as a manufacturer's agent before becoming the paid administrator of the Manchester Yeshiva. ${ }^{17}$

Despite these individual exceptions, Manchester in the mid 1920s, when MH was founded, was still difficult territory for immigrant Jews wishing to remain strictly observant. Until the founding of the MH Society, the orthodox Jews of Manchester formed, in effect, an einheitsgemeinde, a single religiously unified, community. The only real theological opposition to the ruling class that ran institutions such as the communal council, the shechita board and the Jewish charities was the Reform Synagogue and its adherents. There was little organised or effective opposition from the 'right' of the religious spectrum. However, it will be noted throughout this history that, as within any complex religious community, there are continual disputes and rivalries between individual synagogues and their professional and lay leaders.

Such theological opposition from the 'right' might have been expected to come from the Manchester Yeshiva, which was the only institute of higher Jewish learning in the city. Alternatively from the immigrant run Talmud Torah and Central Board for Hebrew Education, founded in Winter Street, Red Bank in 1880 and which concentrated on running the part-time synagogue based khedarim that supplemented the meagre religious education provided at the establishment run Jews' School on Derby Street, Strangeways. ${ }^{18}$ The Talmud Torah had moved to Bent Street, Cheetham in 1889 and over the next half century until World War II, the building was continuously renovated, improved and extended until it became, 'the largest of its kind, not only in Great Britain, but in the Empire. ${ }^{19}$

However, under the control of the Doctors Slotki (Israel and his son Judah) as directors of education from 1911 until 1977, the Talmud Torah gently accommodated the politics of Anglicisation. It ran a curriculum based partly on traditional orthodox

\footnotetext{
${ }^{16}$ It might also indicate the limited number of UK born younger men willing to become politically active in the orthodox cause.

${ }^{17}$ Sufrin, Appointment Diaries of Yosef Chaim Sufrin. Permission granted to quote from the copies in Manchester. Several are overseas and thus unavailable but the Manchester based editions seem very representative according to Rabbi S Z Sufrin, the oldest child.

${ }^{18}$ A comprehensive if heavily sanitised early history of the Talmud Torah can be found in I.W. Slotki, Seventy Years of Hebrew Education (Manchester: Manchester Central Board for Hebrew Education, 1950).

${ }^{19}$ Slotki, Seventy Years of Hebrew Education, 15.
} 
subjects such as Humash Rashi (the Pentateuch with Rashi's commentary) and Siddur (prayer book) with more Wissenschaft subjects such as the Prophets, Hebrew grammar, Jewish history and linguistics. The completely non-observant Samuel Alexander, OM, retired professor of philosophy at Manchester University chaired an official testimonial dinner for Israel Slotki on his receipt of a university doctorate in September 1932. The list of speakers including the directors of education for the cities of Manchester and Salford also gives a clear indication of the direction the institution was heading. ${ }^{20}$

\section{The founding of the Manchester Yeshiva ${ }^{21}$}

The Manchester Yeshiva was founded on Shabbos arben (Saturday night) 25 Shevat 5671 (27 February 1911) when a small group of orthodox rabbis and laymen met and formed the first va'ad hayeshiva (executive committee). The founders were led by Rabbis Yehoshua Dovid Silverstone; Yisroel Yoffey and Menakhem Dagutski, rabbi of the Holy Law and a reverend-supervisor of the Beth Din, and the shokhet and secretary of the Manchester Naturalisation Society (that assisted immigrants in becoming UK citizens), Rev. Hershel Levin. The meeting elected the businessmen Hershel Levinson president, Morris Mason Vice-President and Joseph Cohen treasurer. $^{22}$ The ordinary committee members consisted of rabbis and strictly orthodox immigrant businessmen including the relatives by marriage Elkhonen (Chuna) Heilpern, who by 1917 had become a Vice-President, and Elozor Reich, Hon. Treasurer in 1917, whose inter-related families would become the key force in the development of $\mathrm{MH}^{23}$ Within a few weeks of the initial meeting they had advertised for a rosh yeshiva, held a public meeting in the Talmud Torah hall and had appointed Zvi Hirsh Ferber ${ }^{24}$ as its first principal at a not overgenerous salary of $£ 2$ per week. ${ }^{25}$

\footnotetext{
${ }^{20}$ Slotki, Seventy Years of Hebrew Education, 25. The Talmud Torah's activities declined with the rise of the day school movement after WW2. It finally closed in March 2006.

${ }^{21}$ During the course of my doctoral research I discovered the first Yiddish yeshiva minute books. Those extracts appear to be the first translation into English and the first citation in any work of scholarship.

${ }^{22}$ Manchester Yeshiva (MY) minutes, 27 February 1911, in the possession of Rev. Brodie. Translation from the original Yiddish into English by the writer

${ }^{23}$ MY nomination list for 1917.

${ }^{24}$ See his memoirs - T. Ferber, Zikaron L'Dor Akhron [A Memoir of the Last Generation] (London, 1953).

${ }^{25}$ MY ec 4 March 1911, 18 March 1911, 30 March 1911, and 6 April 1911.
} 
The yeshiva held its first lectures on Sunday 23 April $1911 .^{26}$ The influence of the harēdi immigrants is clear from the use of the heavily ornate, East European dialect of Yiddish ${ }^{27}$ used to record the executive committee minutes, a practice retained until the relatively late date of December $1921 .^{28}$ Ferber resigned in 1913 to become minister of a west London synagogue (and later became a dayan of the United Synagogue) and was replaced by the senior maggid shiur (lecturer) at east London's Eitz Hayim yeshiva, Moshe Yitzhok Segal. ${ }^{29}$

However, whilst the teachers in the yeshiva were themselves strictly orthodox, their ability to influence the standards of religious observance amongst the general population was severely limited. Apart from their natural concern with developing their own institution and its students, they were heavily dependent financially on their small band of active supporters and other wealthy patrons whose voluntary donations were their principal sources of finance. Many of these patrons whilst often acculturated themselves and whilst nostalgic for the simple immigrant orthodoxy of their childhoods (some were what would now be called 'modern orthodox' others barely observant) were certainly far from hassidic or even strictly observant in the German austritt gemeinde or Lithuanian yeshiva traditions. They seemed to combine a very English laissez faire attitude to other people's Judaism - 'it's a free country' with what could be viewed as a rather defeatist belief that somehow the yeshiva was merely holding back a few drops from a tidal wave of assimilation that seemed inevitable. $^{30}$

As the laymen controlled the purse strings they also controlled the rabbis. For example Rabbi Yisroel Yoffey, as chairman of the yeshiva's vaad hahinukh (education committee) published the following anguished cry as part of one of his regular contributions to the Jewish Chronicle. He is writing at a time when the

\footnotetext{
${ }^{26}$ MY ec April 1911.

${ }^{27}$ Often a few English words were incorporated in Hebrew characters or even given Yiddish verb forms.

${ }^{28}$ MY ec 1911-1921.

${ }^{29}$ MY ec 20 September 1913 discussed Segal's appointment and ec 12 October 1913 decided to issue a contract of employment again at $£ 2$ per week.

${ }^{30}$ Notes of an interview with Rev G Brodie, Hon. Secretary and Archivist of MY, 15 August 2001, in possession of the author.
} 
yeshiva had no more than 35 full-time students (some of them from other towns) and 40 part-time, in a city with well over 30,000 Jews:

The environment here is distinctly unfavourable to Jewish learning. There are so many other attractions and distractions for our Jewish youth that every single pupil who attends the yeshiva should be to us a source of rejoicing. With the fire of assimilation raging furiously every such pupil may justly be regarded as an od mazal m'esh - a brand plucked out of the fire... ${ }^{31}$

The lay leaders' deafest attitude is in stark contrast to the Talmudic dictum 'kol Yisroel arveivim zeh l'zeh' (all Jews are co-guarantors, i.e. responsible, for one another), which the sages derived from the laws of debts and surety. ${ }^{32}$ The Talmudic exegesis is that a fully observant Jew is still lacking something important in his religious duty if he does not take steps to assist, encourage and teach his less observant neighbours to be more scrupulous. It was this type of philosophic principle, on a community level if not an individual level, the $\mathrm{MH}$ activists were to use in their forty years war (1925-1965) to improve the standards of Jewish observance in Manchester: a combination of enlightened self-interest and a genuine concern for the survival of Talmudic Judaism.

At taste of what was to lie in store for the other lay leaders of Manchester orthodoxy was the dispute in the yeshiva over the Wallenstein affair. In 1932, Rev. Meir Wallenstein, MA, of London was one of the two candidates for the position of third teacher in addition to Rabbis Segal and Behrmann. Both Chief Rabbi Joseph Hertz and the Rosh Beth Din of London, Shmuel Yitzhok Hillman, endorsed his application. However committee member Hershel Heilpern, by then also the president of $\mathrm{MH}$, alleged he had information that made Wallenstein unsuitable to teach in a yeshiva, in other words, that impugned his standard of orthodoxy. Rather than disclose the source of this information to his fellow committee members, Heilpern apparently incited two of his sons then studying in the yeshiva, Chaim and Aaron Heilpern, to write to the rosh yeshiva, Moshe Yitzhok Segal, stating that should Wallenstein be appointed,

\footnotetext{
${ }^{31}$ Jewish Chronicle, 16 July 1926, 32.

${ }^{32}$ Babylonian Talmud, Tractate Babba Bathra 176a-b and codes.
} 
they would refuse to attend his classes. ${ }^{33}$ The executive naturally took affront at this early attempt to impose student power and veto its right of appointment and asked Segal to suspend the boys pending an apology. During their suspension from classes they wrote a second letter repeating the allegation and refusing to withdraw from their opposition. The executive then asked Yoffey as head of the vaad hahinnukh to investigate. On his report the following ensued during an executive meeting:

[There was] a great deal of very heated discussion, at the end... after unsuccessfully appealing to Messrs $\mathrm{Ch}[\mathrm{una}$ ] and $\mathrm{H}$ [ershel] Heilpern to conform with the wish of the committee and end all strife, ... formally moved that in view of the disturbances and quarrels which had done and were doing incalculable harm to the yeshiva and were caused by Messrs Ch and H Heilpern, that they be suspended from the committee of the yeshiva. ${ }^{34}$

The Heilperns pere and fils withdrew and did not attend any further committee meetings and, instead, devoted their energies to lobbying the shechita board of behalf of $\mathrm{MH}$, the issue that will dominate the rest of their story. Rabbis Segal and Yoffey later persuaded the yeshiva executive to relent to the extent of allowing the Heilpern youths back into class. ${ }^{35}$ Hon. Treasurer Mr L.A. Franks strongly dissenting as he said, 'this was not the first instance in which the Heilperns had defied the committee. A [older] brother of these two [known as Godol from his Hebrew name Gad], having years ago removed from the office wall a picture of the present chief rabbi. ${ }^{36}$ However, Wallenstein lost his chance of a position in the yeshiva and his rival applicant Mr Myers, the candidate favoured by the Heilperns and Rabbi Segal, received the appointment. Wallenstein went on to become a lecturer in Semitic studies

\footnotetext{
${ }^{33}$ Chaim Heilpern declined to comment on this event during my interviews with him seventy years later. Understandably he was very reluctant to discuss any event in which he or his relatives might be subject to written criticism or even direct questioning about their motives.

${ }^{34}$ MY ec 08 June 1932.

${ }^{35}$ MY ec 27 July 1932.

${ }^{36}$ MY ec 17 July 1932. Mr Franks was also upset that the Heilpern boys had found employment as part-time assistant synagogue readers without seeking permission from the committee. Franks resigned as treasurer in September but remained on the committee.
} 
at Manchester University, his Hebrew academic qualifications perhaps one of the reasons for the suspicions of the Heilperns. ${ }^{37}$

The Manchester Yeshiva was founded to recreate the curriculum of the Lithuanian yeshivos - Talmud and legal codes being the principal texts and the language of instruction being Yiddish. As the enlightenment and later the Zionist movement gathered momentum in Eastern Europe there was a reaction in the yeshivos to minimise the importance of subjects favoured by the maskilim: Hebrew linguistics, the books of the Prophets and the academic study of Jewish history. Temptation first came to the yeshiva in February 1924. The executive received a letter from the Jewish War Memorial Manchester Area Committee ${ }^{38}$ to the effect that it had decided to make the yeshiva a grant of $£ 50$ subject to conditions. It stated, 'That an additional teacher be engaged who shall teach Hebrew grammar, Tenakh (Bible) and in particular Neviim Akhronim (the later Prophets), Jewish history and that further, that the instruction in these subjects be given in English. ${ }^{39}$ Despite the yeshiva's precarious finances, Mr Harris Halpern (one of the English born MH members and owner of a large woollens business in Derby Street, Cheetham) moved a motion to reject the grant because of the conditions attached. The secretary was instructed to reply that the yeshiva could not accommodate the committee's conditions and that it had its own education committee to look after such things.

\section{The first leaders of independent orthodoxy and their environment}

Thus the founding of a Manchester Machzikei Hadass Society in the summer of 1925 would not come about in a vacuum either of time or of space. From their arrival in the 1890s and early 1900s, all the founding families had been involved with the leading institutions of mainstream Manchester orthodoxy. Three generations of Reichs and Heilperns had become leaders of the Polish Synagogue in Strangeways and Hershel Heilpern had served as a delegate of that institution on the council of the Manchester

\footnotetext{
${ }^{37}$ He published several papers on Biblical topics in the bulletin of the John Rylands Library in the 1950s and 1960s. He is mentioned in the fiftieth anniversary article in Journal of Semitic Studies 1, 1 (Spring 2005). The JSS was founded and managed by the academic staff of Manchester University.

${ }^{38}$ The Jewish War Memorial Committee was based in London under the chairmanship of the industrialist Sir Robert Waley Cohen later President of the United Synagogue.

${ }^{39}$ MY ec 24 February 1924.
} 
Shechita Board. The future MH president and activist Wolf Dresdner had become spiritual leader of the Austrian Synagogue in Waterloo Road, Hightown. Several Heilperns, Reichs and other MH members served on the committee of the Manchester Yeshiva from its inception and throughout the 1920s and 1930s, Elozor Reich serving as Treasurer from 1917 to the early 1920s and his grandson Hershel Reich acting as Treasurer from 1931 to $1934 .{ }^{40}$ The Sufrins were leaders of the Romanian Synagogue and active in the local Agudas Yisroel association. MH supporters Wolf Jaffe and his non-related neighbour Mottle (Mordechai, Maurice) Jaffe of Halliwell Street, Cheetham were prominent leaders of and financial powers in the Lubavitch hassidic community. ${ }^{41}$ Isaac Galansky in whose home the MH weekday minyan met from 1933-34 until it acquired its own building in 1938 was a former warden of the Holy Law Synagogue:

Although he [MH's Rabbi Feldmann] prayed mostly at the Polish Synagogue (now defunct) the community now [in the mid 1930s] had adherents at the Austrian, Rumanian, Central, Kehal Chassidim, New and Holy Law synagogues amongst others. ${ }^{42}$

This association with other local orthodox institutions continued even after $\mathrm{MH}$ acquired its own professional leaders and its own permanent buildings. Soon after his arrival in Manchester in December 1934, MH's founding rabbi Dovid Feldmann became intimately involved with the yeshiva although he was never an official member of the teaching staff. By February 1936 he was a speaker at the biennial prize giving ceremony, which in the 1930s was usually chaired by Reuben Barrow-Sicree as president of the Shechita Board, and at the AGM of 1937 Feldmann was deputising for the chairman of the education committee. At that meeting he declared: 'the yeshiva was Manchester's most essential institution and one which deserved its [the community's] utmost support. ${ }^{43}$ Feldmann used to feher (test) yeshiva students on their studies as an external examiner, and occasionally lectured at the yeshiva. ${ }^{44}$ The

\footnotetext{
${ }^{40}$ Entries in MY ec minute books. A copy of the nomination list for the yeshiva committee elections of 2 September 1917 is in the possession of the author.

${ }^{41}$ Papers relating to Wolfe Jaffe held by his grandson Abraham, minister of the New Kehal Chassidim Synagogue, Salford. Details of Mottle Jaffe held by his grandson Frank Beigal, Chairman of the Jewish Historical Society of England, Manchester branch.

${ }^{42}$ Speech notes of J.J. Reich for the dinner marking the official opening of the new MH synagogue, 16 September 1962. Permission granted.

${ }^{43}$ MY ec, 2 February 1936 and 18 April 1937.

${ }^{44}$ Jewish Chronicle, 4 June 1937, 32.
} 
leading MH families continued to send their sons to study in the yeshiva both as parttime students after grammar school ${ }^{45}$ and as full-time students before they went into business or trained for a profession. They were also instrumental in helping the yeshiva to resist the blandishments of 'modern orthodoxy' and the Wissenschaft des Judentums school of 'historic Judaism.'

The local Jewish leadership had been working hard for over forty years at the acculturation of such 'foreign Jews' into lower middle class, gentile society. Community leaders such as communal council president, the wealthy cotton merchant, Nathan Laski, youth work leader Colonel Edward C.Q. Henriques and the Shechita Board president, the suave Sephardi solicitor Reuben Barrow-Sicree were neither strictly observant themselves nor in favour of any institution that encouraged too much east European style orthodoxy. ${ }^{46}$ Although some like Barrow-Sicree and Mark Bloom, the affluent raincoat manufacturer who was the major financial supporter of the yeshiva were pleased by the status conferred on them by chairing orthodox institutions and bodies that their own children would never attend as students nor become members of. 'Their lives consisted, in fact, of striking a balance between a total commitment to Judaism and full participation in the life of the urban bourgeoisie. $^{47}$

Consequently the Beth Din and Shechita Board were grossly under-funded, their religious authorities undermined and ignored and their customers sometimes duped by a small minority of unscrupulous butchers, bakers and other retailers. ${ }^{48}$ Yiddish was banned at the Manchester Jews' School as learning the English language was an important first step towards anglicisation. ${ }^{49}$ Many of the brightest children won scholarships and went on to secondary education in elite English schools like Manchester Grammar, Salford Grammar and Manchester High School for Girls. After

\footnotetext{
${ }^{45}$ Several are listed amongst the alumni of Manchester Grammar School in the school archives.

${ }^{46}$ Nathan Laski was what would now be called 'traditional,' Henriques was a member of the Reform synagogue and Barrow-Sicree was a lukewarm member of the Manchester Sephardi community. All enjoyed being big fish in the small pond of the Manchester Jewish establishment.

${ }^{47}$ Williams, The Making of Manchester Jewry 1740-1875, 86.

${ }^{48}$ Interview with the late Rabbi R. Margulies of Manchester Yeshiva, brother of Rev. Sigmund Margulies who was Clerk of the Manchester Beth Din and Shechita Board after WW2 and MSB minutes, June 2001, in the possession of the author.

${ }^{49}$ R. Livshin, 'Acculturation of Immigrant Jewish Children 1890-1930' in D. Cesarani, ed., The Making of Modern Anglo-Jewry (Oxford: Blackwell, 1990).
} 
school they might participate in the Jewish Lads' Brigade or the Manchester Jewish Girls' Club, formed to complete their acculturation to the British ideals of 'playing the game' and being a 'jolly good sport.' As they grew up they could join the Manchester Jewish Cricket Club, the Jewish Literary and Social Union or one of Jewish run Masonic lodges. One of the most famous children of this system was Louis Golding, born in Manchester to immigrant parents, a scholarship boy at Manchester Grammar School and Queen's College, Oxford who immortalised his childhood in his 1932 novel Magnolia Street. Another Louis, the controversial minister, scholar and academic Dr Louis Jacobs, CBE, born in Manchester in 1920, recalls some of his early experiences in his 1989 autobiography: 'The Jews' School in Manchester, like its counterpart, the Jews' Free School in London, was established in the last century with aim of helping the children of Jewish immigrants become fully integrated into English society. All the teachers were staunch English patriots. ${ }^{50}$

During the childhood of Jacobs' parents there had been at least twenty hevros in Manchester, varying in the precise form of their religious life, but dedicated as a whole to the strictest religious standards of the east European ghetto. ${ }^{51}$ Although vulnerable to the overwhelming forces of socialisation, directed towards them in part by the Jews' School and the Manchester Jewish Board of Guardians, the hevros were sustained by a flow of migration that kept up until the First World War. And by a line of the most uncompromising Polish and Lithuanian rabbis, of whom the prototype was Sussman Cohen of the Hevra Walkawishk (later renamed the Central Synagogue), who became a part-time 'reverend supervisor' of the Shechita Board. ${ }^{52}$ Looked on with growing disdain by the more acculturated leaders of Manchester Jewry, the hevros served in many ways to underpin the whole religious structure of the community by providing a constant source of fresh inspiration from the fount of Jewish orthodoxy. ${ }^{53}$ One of their prominent leaders, Yisroel Yoffey, was an elegant preacher in Yiddish as his collection of Manchester sermons Knesses Yisroel, published in Manchester in 1910, testifies. He went on to do sterling work under extremely difficult circumstances at the Manchester Beth Din and later became president of both the Manchester Agudas Yisroel and the Manchester Mizrachi

\footnotetext{
${ }^{50}$ L. Jacobs, Helping with inquiries (London: Vallentine Mitchell, 1989), 8.

${ }^{51}$ The MSB annual reports always list its affiliated synagogues, M448 MCL.

${ }^{52}$ He later became a member of the London Beth Din - court of the chief rabbi.

${ }^{53}$ Williams, The Making of Manchester Jewry, 325.
} 
Federation. ${ }^{54}$ By the time Louis Jacobs was born these 'founts of orthodoxy' were rapidly drying up and the acculturation of the younger generations giving grave cause for concern to the more orthodox stalwarts. ${ }^{55}$

At the turn of the 20th century, differences between native and immigrant Jews in both London and Manchester were still profound. To the former, the newcomers seemed uncivilised, to the latter some of their co-religionists seemed scarcely Jews at all. Even sociologists and economists quickly realised the chasm in ideology that existed between those fervently attempting to cling to strict orthodoxy and those desperate to climb over the ghetto walls and into the Elysian fields of middle class security and Christian acceptance (italics mine):

There appears to be almost a stronger line of severance between the English and foreign Jew than between the English Jew and gentile. In habits, ideas and religion they are fundamentally distinct; and when they come too much into contact there is even mutual hostility and contempt... the bitterest enemies of the foreign immigrant that I have come across have been English Jews; while the foreigners are commonly shocked and scandalised at the laxity in faith, and the shamelessly 'non-observant' lives of their English co- religionists. The English Jew, moreover, is often an ardent patriot; he is proud of being an Englishman, and seems generally to regard his foreign co-religionists from the English rather than the Jewish standpoint. ${ }^{56}$

The sociologists, Russell and Lewis, go on to explain that English Jews have a higher social standing and it is the parvenu of the East End who most despises the Yiddishspeaking sector of the community. Part of the effect produced by this schism in the community was to emphasise the association of 'extreme orthodoxy' with the speech, habits and general social inferiority of foreigners. That is to say, in a majority of the community, and especially in the rising generation, it will serve to hasten the process of alienation from 'strict orthodoxy.' In many quarters orthodoxy had already fallen

\footnotetext{
${ }^{54}$ Jewish Chronicle, 16 March 1923, 13, 27.

${ }^{55}$ Interview with Isadore Yoffey, youngest son of Yisroel Yoffey, 26 March 2006, in the possession of the author.

${ }^{56}$ C. Russell and H.S. Lewis, The Jew in London: A study of racial character and present-day conditions (London: T. Fisher Unwin, 1900), 186-191.
} 
into contempt through being associated with foreigners of the lowest social grade. They even quote an English Jew who assured them, 'with a grave countenance,' that orthodoxy and dirt always went together; and that the former was invariably found to vanish under the influence of soap and water. They also found that the contempt, which the 'Englishman' of the Jewish community entertains for the 'foreigner' is heartily reciprocated. ${ }^{57}$

\section{Communal politics and the social network of the MH leadership}

Soon after the founding of the international harēdi political organisation the Agudas Yisroel in 1912, a small branch was established in Manchester together with a chapter of the Agudist youth movement Sinai. ${ }^{58}$ The local Aguda had no regular venue and met in various synagogues including the Polish, the Austrian and the Kehal Hassidim (Lubavitch). ${ }^{59}$ There were 'Aguda shiurim' given by strictly orthodox rabbis and lay leaders such as Gedalia Rabinowitz and special events such as public meetings to welcome visiting European notables collecting donations on behalf of their impoverished yeshivos. One of the most publicised was a meeting held at the Broughton Assembly Rooms on 9 March 1930 to welcome Yitzhok Isaac Sher, Rosh Yeshiva of Slabodka who was supported by Isaac Herzog, chief rabbi of Ireland and Yisroel Yoffey. ${ }^{60}$ Manchester's $\mathrm{MH}$ with greater determination and a separatist ideology was to build its own organisation and revive the local branch of the Agudas Yisroel on the foundations laid down by these previous generations of immigrants and their 'foreign rabbis' in both London and the provinces.

As already noted, $\mathrm{MH}$ activists took part in the affairs of several leading institutions within Manchester's wider orthodox community, principally the yeshiva and the local shechita board, from the early 1900s until the final break with what had become modern orthodoxy and religious-Zionism in the mid 1960s. Following their parents and grandparents onto the yeshiva executive were several $\mathrm{MH}$ males who were also former students. In the manner of younger sons of the aristocracy sitting as English members of parliament for 'rotten boroughs' before the 1832 Reform Act, MH

\footnotetext{
${ }^{57}$ Russell and Lewis, The Jew in London.

${ }^{58}$ Jewish Chronicle, 1 November 1912, 30.

${ }^{59}$ Sufrin, Appointment Diaries of Yosef Chaim Sufrin.

${ }^{60}$ Sufrin, Appointment Diaries of Yosef Chaim Sufrin.
} 
activists often represented other, less political, orthodox organisations rather than $\mathrm{MH}$ itself. This allowed them to intervene in local and national Jewish politics whilst presenting an image of the $\mathrm{MH}$ organisation itself as above the tawdry business of communal infighting. For example MH President Hershel Heilpern's son Chaim Heilpern, its part-time minister, represented the almost defunct Warsaw Synagogue of Hightown and later the Initiation Society - the society of mohelim (circumcisers) - on the BoD for over 50 years. He also represented the modern orthodox United Synagogue, Manchester, with which he had been associated since his days as a yeshiva student, on the local communal council and later represented the Initiation Society well into his $90 \mathrm{~s} .{ }^{61}$ This 'rotten boroughs' phenomenon would become more noticeable after 1965 when $\mathrm{MH}$ regarded itself as an austritt gemeinde and when official organisational membership of general community institutions would have been blatantly incongruous.

In contrast to these somewhat covert activities, the Yesode Hatorah synagogue later the Machzikei Hadass synagogue, would be fully represented, unashamedly under its own name, on the council of the MSB. The MSB was the principal Jewish citadel that demanded to be stormed and, if at possible, to be captured for undiluted orthodoxy. It was the forum that controlled the community's kashrus, its Beth Din and its mikvos. Constitutionally it was solely orthodox whereas both the local communal council and the national BoD were both 'tainted' in $\mathrm{MH}$ eyes by Reform, Liberal and secular memberships. Ipso facto it was also the wealthiest orthodox institution, one that had won for strict orthodoxy or at least made to submit in regard to allowing a separate and, if necessary, an independent shehita. Thus it was at MSB meetings that the most combative of the young MH leaders won their debating spurs, often returning to Northumberland Street verbally bruised but undeterred, soon ready to plan their next political campaign for the 'strengthening of orthodoxy', i.e. for the expansion of MH.

In addition to the formal meetings of the various communal institutions both in Manchester and London, were the informal contacts that various $\mathrm{MH}$ leaders maintained to facilitate 'backstairs' intrigue and information. MH's Dovid Feldmann

\footnotetext{
${ }^{61}$ He stopped attending meetings in the 1990s unless there was an issue that excited his disapproval or concern.
} 
would naturally have close friendships with his few fellow strictly orthodox rabbis Yeheskiel Abramsky and his fellow members of the London Beth Din; Naftoli Shakovitsky, the first Gateshead Rov; Moshe Yitzhok Segal, the Manchester Rosh Yeshiva, and Dr Solomon Schonfeld, leader of London's Adath Yisroel communities among them. ${ }^{62}$ Former MH President Lazar Dovid Brunner asserts that even Chief Rabbi Israel Brodie had one policy for $\mathrm{MH}$ in public and another for private communication: 'Rabbi Brodie helped us as much as he could, under the table, especially towards the end [of his career].' 63

\section{Social networks and émigré ideology}

The MH lay leaders maintained their own social networks, greatly assisted by the fact that many of them were related by birth or by marriage. For example the younger Reichs, Heilperns and Halperns in addition to being first cousins themselves, all had brothers-in-law and mekhutonim (a child's parents-in-law) in Gateshead and in London. ${ }^{64}$ Later these family contacts would extend to community leaders in Antwerp, New York, Jerusalem and Bnei Brak. The wife of Lazer Dovid Brunner, a member of the MH executive from 1944 and from 1965 the president of the MH synagogue and community is a first cousin of the late Dr Bernard Homa, London County Councillor; chairman of the BoD shechita committee, a leader of the Federation of Synagogues and president of the London Machzikei Hadath. ${ }^{65}$ This 'cousinhood' was in reality a harēdi version of the 'cousinhood' of wealthy brokers and bankers that ruled AngloJewry in the 19th century; a term coined by Chaim Bermant and others. ${ }^{66}$ Often, close friendships (and occasionally lasting enmities), were formed by activists who, as yeshiva students, had studied together in Gateshead, Manchester, London or elsewhere. This phenomenon, generally unexplored by the academy in regard to orthodox Jews, is a classic case for analysis in social network theory. 'The logical

\footnotetext{
${ }^{62}$ Information on rabbinical contact networks provided by Rabbi Bezalel Rakow, 1927-2004, the late Gateshead Rov (Shakovitsky's successor). Abramsky's correspondence is in the London Beth Din Archives. A brief biography of Schonfeld has recently been published. See D. Kranzler, Holocaust hero: the untold story and vignettes of Solomon Schonfeld, an extraordinary British orthodox rabbi who rescued 4,000 during the Holocaust (Jerusalem: KTAV Publishing House, Inc., 2003).

Much of the correspondence of the chief rabbis from Nathan Adler to Jonathan Sacks is in the London Metropolitan Archives: ACC/2805 Office of the Chief Rabbi.

${ }^{63}$ Interview with Mr L D Brunner, 25 September 2003. Perhaps in return for the MH support the chief rabbi had received over the Jacobs affair?

${ }^{64}$ Based on the Reich family tree produced by Mr L. Reich.

${ }^{65}$ Interview with Mr L.D. Brunner, 25 September 2003, in the possession of the author.

${ }^{66}$ C. Bermant, Troubled Eden: an anatomy of British Jewry (London: Vallentine Mitchell, 1970).
} 
complications of kin relationships can be quite complex and formal network mathematics can help to specify the implications of such matters as bilateral crosscousin marriages in which one's wife is also both mother's brother's and father's sister's daughter. ${ }^{67}$

In other words, orthodox Jews, like other groups, have informal social networks that are invisible to outsiders but critical to the efficient operation of both their social institutions and their daily lives. Accordingly even where the tribe (e.g. the $\mathrm{MH}$ families) has an explicit 'official' kinship system it does not follow that one knows the norms applied to actual behaviour of individuals, much less the extent to which behaviour conforms to the norms. A mass of data on perceived norms, local horde membership, descent groups, kinship terms used for one another by at least a large fraction of tribe members, together with extensive records of marriages containing all such information for both spouses is necessary. This will establish a system to which various aspects of kinship behaviour in a tribe may conform in fact or in principle. Nothing like this quantity of data is presented in existing accounts of an orthodox Jewish community's kinship behaviour. To date, no anthropologist has gathered the volume of systematic data required for full analyses of kinship systems of orthodox Jewish communities. But it was just these informal kinship networks that helped the independently minded families of Manchester, London and Gateshead eventually outmanoeuvre the Anglo-Jewish leadership and establish their own independent orthodox communities.

The other factor was the continuing ability to transmit what Shapiro and other American scholars call 'an émigré rather than immigrant' ideology to their descendents. Unlike most other newly arrived Jews from eastern Europe, the $\mathrm{MH}$ families came through force of economic circumstance bringing their belief system intact and transplanting it to a western society. ${ }^{68}$ They were not 'immigrants' looking for a better life and therefore willing to adapt to a superior culture; they were 'émigrés' who brought their culture with them and, referring back to their history and

\footnotetext{
${ }^{67}$ C. Kadushin, A Short Introduction to Social Networks: A Non-Technical Elementary Primer (New York: Cohen Centre for Modern Jewish Studies, Brandeis University and Graduate Centre City University of New York, 2000).

${ }^{68}$ For the economic conditions then prevailing in the Brody region see T. Gasowski, 'Jewish communities in autonomous Galicia' in A. Paluch, ed., The Jews in Poland (Cracow: Jagiellonian University, 1992), 205-221.
} 
their leaders in Poland, found them generally superior to that of the indigenous gentile and generally acculturated Jewish population in Manchester. ${ }^{69}$

\section{The religious politics of the Jewish community}

Manchester was an early centre of religious Zionism in England. An international organisation called Mizrachi (from the Hebrew Merkaz Ruhani - 'Spiritual Centre') was founded in Europe in Adar II 5662 (March 1902) by rabbis who considered it a sacred duty to ensure the building of Eretz Yisroel as the national home of the Jewish people on the basis of Talmudic Judaism. The party was founded at a conference of religious Zionists convened in Vilna (Vinius) by Isaac Jacob Reines (1839-1915), who served as the organisation's first president. ${ }^{70} \mathrm{~A}$ controversial and enterprising figure, in 1905 Reines established the first 'modern orthodox' yeshiva in Eastern Europe, in Lida, Lithuania. ${ }^{71}$ Here the traditional Talmudic curriculum was combined with practical secular subjects. Reines argued that orthodoxy would be at a disadvantage as long as religious Jews could not achieve economic independence. The ideology of the Mizrachi movement regarded Jewish nationalism as an instrument for realising religious objectives, especially of enhancing the opportunities for the observance of the Torah by a Jewish nation dwelling on its own soil. ${ }^{72}$ Reines spent three months in Manchester in 1884 where he had been offered a position in one of the leading synagogues and where a daughter was married to Rabbi Sussman Cohen. However 'the state of Judaism in England dismayed him' and he returned to Russia. ${ }^{73}$

Although several attempts had been made in London to start Mizrachi groups, the movement only really prospered in England following the first national conference of Mizrachi held in Manchester in December 1918, which led to the opening of the Mizrachi Bureau in London. ${ }^{74}$ The conference was organised, almost single-handedly, by Yisroel Yoffey, who had furthered the cause of religious Zionism since his

\footnotetext{
${ }^{69}$ E. Shapiro, 'Modern Orthodoxy in Crisis: A Test Case', Judaism 51:3 (Summer 2002), 347-362.

${ }^{70}$ H. Z. Reines, 'Isaac Jacob Reines' in L. Jung, ed., Jewish Leaders 1750-1940 (Jerusalem: Boys Town Jerusalem Publishers, 1964), 275-293.

${ }^{71}$ An earlier attempt in Shwenzian, Lithuania had failed financially in 1883.

${ }^{72}$ Z.Y. Wise, The sacred and the profane: conflicting views of nation, nationality and governance in the State of Israel, unpublished MA thesis (University of Salford, 2000), Chap. 1.

${ }^{73}$ Reines, Isaac Jacob Reines.

${ }^{74}$ Interview with Isadore Yoffey, 26 March 2006. Mr Yoffey has a copy of the minutes of the conference.
} 
appointment at the Central Synagogue in $1897 .{ }^{75}$ Yoffey preached Zionism from the pulpit (mainly in Yiddish) in spite of some local criticism, targeted the more orthodox with success, and was an effective fund-raiser. His was highly active in promoting religious education among the young in Manchester, hence his chairmanship of the yeshiva's education committee, and was also influential in establishing Mizrachi societies in Glasgow, Sunderland and Sheffield. ${ }^{76}$ Chaim Weizmann, by then in London, sent a message of support to the 1918 Manchester conference, but feared and opposed the Mizrachi. He regarded it as the enemy within because he felt that it fostered the sort of nationalism that would eventually lead to 'religious dogmatism'. ${ }^{77}$

Manchester was also an early centre for Socialist Zionism. The Zionist Workers or Poale Zion was formed in Austria following the sixth Zionist congress of 1903. Despite the fact that at the turn of the century most British Jews were Liberal Party supporters, branches of Poale Zion were soon established in London, Manchester, Liverpool, Leeds and Glasgow. The first British conference of the Poale Zion was held in Manchester in April 1906. ${ }^{78}$ However the Manchester branch was neither a large nor a well-organised society. ${ }^{79}$ In the early 1930 s, at a meeting with only twelve people present, four of whom were speakers, the debate raged: 'Would Herzl have put on tephillin if he'd known their importance?' In contrast to his attitude to the religious Zionists, Weizmann always regarded the national Poale Zion movement with respect and with a measure of envy due to its popularity amongst the working class. ${ }^{80}$

In contrast to the Zionists, both religious and secular, the non-Zionist orthodox of the Agudas Yisroel were relatively inactive from their late start in 1912 until after the Great War. ${ }^{81}$ Their main bases of operation, the Pale of Settlement and Germany, had

\footnotetext{
${ }^{75}$ Information from Mr Isadore Yoffey. See also Yoffey Papers, M648, Archives, MCL.

${ }^{76}$ Additional information on the Mizrachi in Manchester from the Yoffey Papers, Archives, M648, MCL.

${ }^{77}$ In other words that any independent state might be 'too Jewish.' See M. Weisgal ed., The Letters and Papers of Chaim Weitzmann Vol. 3 Series A (London, 1972).

${ }^{78}$ P. Goodman, Zionism in England 1899-1949 (London: Zionist Federation of Great Britain, 1949), 45.

${ }^{79}$ For a brilliant analysis of the divisions and personality clashes involved in the UK see E. Black, 'A typological study of English Zionists' in Jewish Social Studies 9.3 (Indiana, 2003), 20-55.

${ }^{80}$ J. Meltzer, Chaim Weizmann: The Manchester period, prelude to the Balfour declaration (London, 1973), 11.

${ }^{81}$ Aguda members fought on both sides of the conflict as did other Jews. A 1917 open letter from the Vienna office asked Jews not to buy yahrzeit (remembrance) candles but instead donate the money to the Austrian war effort. It is reproduced on www.virtualjudaica.com.
} 
been engulfed in that conflict and the Russian revolution from 1914 to 1918 . In 1919 the leaders of the Aguda met in neutral Zurich to discuss how to repair the immense damage the war, on the eastern front between the Kaiser and the Tsar, had wrought to the Jewish communities of Lithuania, Poland, Belarus and the Western Ukraine. In addition to death and disruption of family life and the razing of entire villages, most of the yeshivos and hassidic courts had also been uprooted and dispersed. ${ }^{82}$

The Aguda leaders adopted the temporary name of Weltkonferenz der Juedischorthodox verbände (World conference of orthodox Jewish organisations) as Agudas Israel was believed to be identified as a German based organisation and therefore possibly unappealing to the victorious allies. ${ }^{83}$ Because of the desperate poverty now common across eastern Europe the Aguda leaders agreed to send emissaries to western Europe, Britain and North America to raise funds and to spread the Aguda message to the more traditionally minded migrants of the western world. ${ }^{84}$ Individual orthodox leaders also backed the campaign:

In the immediate post-war years the poverty amongst the Jews of Poland was such that most of the people were literally hungry for bread. Reb Avrohom Mordechai [Alter, the third Rebbe of Ger, 1866-1948] therefore despatched learned rabbonim to central Europe and to Britain in order to raise funds. ${ }^{85}$

Several of these rabbinical emissaries came to Manchester and during their visits provided up-to-date information on the political situation in der alter heim. By 1920 the Aguda's Manchester branch was claiming a membership of two hundred adult males who were meeting regularly under the presidency of Yisroel Yoffey. ${ }^{86}$ In that generation there was no problem in a leader belonging to both the Mizrachi and the Aguda, at least outside Eretz Yisroel and Yoffey continued to hold the presidency of the Manchester Mizrachi. The antagonism between the two religious-political movements developed later as the reality of a polity in the form of a Jewish state came

\footnotetext{
${ }^{82}$ A. Mittleman, Agudat Israel: The Politics of Torah: The Jewish Political Tradition and the Founding of Agudat Israel (Albany: State University of New York, 1996), 133.

${ }^{83}$ Footnote 102 to Chapter 3 in Mittleman, The Politics of Torah.

${ }^{84}$ G. Bacon, The Politics of Tradition: Agudat Yisrael in Poland, 1916-1939 (Jerusalem: The Hebrew University Magnes Press Ltd., 1996).

${ }^{85}$ A. Bromberg, Der Rebbes of Ger (Jerusalem, 1952), 157.

${ }^{86}$ Manchester entry in Jewish Yearbook (London, 1920 edition).
} 
ever closer. ${ }^{87}$ In December 1921 a Broughton branch of the Aguda's children's organisation Sinai was launched to encourage younger boys and girls to socialise together in a suitably orthodox environment. ${ }^{88}$

In Ellul 5683 (August 1923) the first major Aguda international conference since the end of the war was held in Vienna where the central office had transferred from Zurich. Known as the Knessia Gedola, it was attended by hundreds of rabbinic and lay leaders from all over the world including eastern and western Europe, North America, mandate Palestine and Britain. There was a small British delegation was led by Zvi Hirsh Ferber, the former Manchester Rosh Yeshiva then a Dayan of the London Beth Din, and Julius Jung of London's Federation of Synagogues, and one of the designated chairmen of the three European branch offices - London, Vienna and Warsaw. ${ }^{89}$ The 1923 conference seems to have initiated a new wave of orthodox activism throughout Europe not least in the United Kingdom. Three out of five members of the international political executive committee came from London including Ferber and Harry Goodman, JP, who was to become the principal lay leader and spokesman of the UK Aguda throughout the period of the British mandate over Palestine. $^{90}$

Within six years of their return from Vienna the leaders of the relatively small harēdi communities of England had founded new organisations that were to have a profound effect on the development of British orthodoxy. Belzer hassidim in Manchester initiated a Machzikei Hadass Society (1925); Victor Schonfeld of London's German Adath Israel Synagogue launched the Union of Orthodox Hebrew Congregations (1926) and the Lithuanians of Gateshead officially founded their Yeshiva Gedola, which would become the largest east European style yeshiva in western Europe (1929). They believed that the time was ripe to begin a new era in the history of Anglo-Jewry. ${ }^{91}$

\footnotetext{
${ }^{87}$ G. Bacon, 'Imitation and Rejection: Agudat Yisroel and the Zionist Movement 1912-1939,' in S. Eisenstadt and M. Lissak, eds., Zionism and the Return to History: A Reappraisal (Jerusalem: Yad Ben-Zvi Press, 1999).

${ }^{88}$ Sufrin, The Appointment Diaries of Yosef Chaim Sufrin.

${ }^{89}$ For a brief report of the conference in German see P. Kohn, Geschaftsbericht ersttet der ersten kenessio gedaulo von dem geschaftsfuhrenden ausschuss der Agudas Jisroel (Wien, August 1923). Copy held in the Jewish National Library, Jerusalem.

${ }^{90}$ Jewish Chronicle 24 August 1923; 14 and 31 August 1923, 15.

${ }^{91}$ New orthodox organisations were also founded elsewhere such as the Swiss IRG of Basel, 1927.
} 


\section{The founding of Manchester's Machzikei Hadass}

According to the late Rev. Chaim Heilpern, an elder statesman of the independent orthodox community until his death several years ago, Manchester's Machzikei Hadass organisation had its origins in a meeting in 'the summer of 1925.' There is no surviving record of the exact date but there is circumstantial evidence indicating it could have been sometime in August. ${ }^{92}$ All but one of the founders who met in the house of Hershel Heilpern, were Brody immigrants and Belzer hassidim who had come to Manchester about $1900 .^{93}$ Like Hershel Reich, Hershel Heilpern had married a daughter of Eliezer Adler, the leader of the strictly orthodox Gateshead community in 1908. His son Chaim Yaakov was born in Gateshead in 1914 and was present, 'under the table,' during the 1925 meeting. ${ }^{94}$ Later the young boy and his brothers would go door to door, collecting the subscriptions that would fund the new organisation. Hershel Heilpern lived at 93 Camp Street, Higher Broughton, then a chosen area of residence for successful Jewish tailors and other small businessmen. ${ }^{95}$ Almost all the founder members at the initial meeting prayed at the Polish or the Austrian Synagogues nearby. ${ }^{96}$ In addition to the Heilperns, Elkhonen (known as Chuna) and Hershel, amongst those present at the initial meeting were Alter Grosskopf, Wolf Dresdner, Uren (Aaron) Reich, his son Hershel Reich and Ayreh Leib (Leonti) Sufrin of the Romanishe shul. ${ }^{97}$ All except Sufrin were Belzer hassidim from Brody and had grown up within the MH movement of Galicia. The Sufrins, immigrants from Jassy, Romania, were to become a well-known orthodox family, and several were later associated with the development of Lubavitch hassidus in both London and Manchester. ${ }^{98}$ The head of the Sufrin family, Aryeh Leib's father Isadore

\footnotetext{
92 The appointment diaries of Yosef Chaim Sufrin surprisingly omit the event but he was on holiday in Blackpool in August 1925. The months I consider most likely for the meeting are June, July and August i.e. between Shavuos and Rosh Hashona. Mr Heilpern concurred with this hypothesis.

${ }^{93}$ Lipman claims that there was a large influx of Galician Jews to the UK between 1890 and 1902. See V. Lipman, Social history of the Jews in England 1850-1950 (London: Watts and Co., 1954), 88-89. This fits with the establishment of several Galician shteibls in Manchester - including the Polish, Austrian and Broder.

${ }^{94}$ Interview with Chaim Heilpern, 21 October 2001, in the possession of the author.

${ }^{95}$ The author's great grandfather Chaim Yehiel Wise-Cohen, a master tailor, lived at 6 Upper Camp Street, Higher Broughton until 1934 and would have been a customer of the fent dealers.

${ }^{96}$ Interview with Chaim Heilpern, 21 October 2001, in the possession of the author.

${ }^{97}$ Synagogue membership did and does not prevent individuals from attending events at other nearby venues even on a regular basis. Members from other synagogues regularly attend shiurim (lectures) at all the strictly orthodox venues. Virtually all orthodox adult activities operate an 'open door' policy.

${ }^{98}$ Information from the late Rev Aron Dov Sufrin, Educational Director of London's Lubavitch Foundation and Rabbi Shlomo Zalman Sufrin of Manchester, grandsons of Isadore Sufrin.
} 
(Yitzhok), was a linen draper with premises at 243 Bury New Road, Higher Broughton, then a northern suburb of choice for the lower middle class. Other prominent Lubavitch leaders such as the Jaffes provided, at a local level, a link to the MH campaign of Lithuania and Russia in the first years of the 20th century.

All the Belzer hassidim from Brody at the first meeting were fent dealers. Of the approximately one hundred and fifty fent dealers and merchants in Manchester in 1925, one hundred and twenty were Jewish. ${ }^{99}$ Fent dealers (the word is old English for vent meaning a slit) bought up complete bolts and small rolls of cloth usually between five and twenty metres from textile manufacturers and larger wholesalers who had been left with 'ends' of a run of cloth and discontinued lines. These were perfect stocks which had been printed or dyed but were either too small for general sale to major customers or no longer in current production. ${ }^{100}$ The orthodox Jewish fent dealers brokered these oddments to small workshops, dressmakers and tailors, many of them also Jewish, to use in small-scale production of men's suits or ladies' costumes and so forth. The MH families involved in the fent trade included the Dresdners, the Grosskopfs, the Heilperns, the Vogels, the Rosenstraughs and the Reichs. All had combined office-warehouses in Manchester city centre in the small streets off Princess Street. ${ }^{101}$

Most of the initial MH members originally lived about two miles north west of the city centre in the generally respectable working class district of Lower Broughton near the Polish Synagogue. By contrast, the anglicised leaders of the general orthodox community in 1925 such as Nathan Laski were merchants and manufacturers on a much grander scale. They lived in substantial villas in middle class suburbs such as Cheetham, Higher Broughton and Didsbury. It was partly this class difference in addition to conflicting philosophies regarding the decree of acculturation required to live successfully in England that would prove to be the elite's Achilles heel. They would find it difficult to accept what they considered to be a motley group of petit bourgeois, parvenu immigrants as worthy opponents in serious negotiations over the administration of a major Jewish community.

\footnotetext{
${ }^{99}$ Kelly's Directory of Manchester \& Salford (Salford Central Library, 1925).

${ }^{100}$ Information from the Manchester Museum of Science and Industry, textile division.

${ }^{101}$ MH members had offices in Bloom St., Major St., Minshull St., Faulkner St., Turner St, Sackville St. and York St., Kelly's Directory of Manchester \& Salford.
} 
At the initial 1925 meeting the small group of hassidim decided to follow the Galician and Lithuanian models and oppose what they perceived as the steep decline in orthodox Jewish standards. They resolved to set up a local Machzikei Hadass Society and decided that the initial raison d'être of their new organisation was to improve what its members considered to be the very poor standards of Jewish food supervision in Manchester at the time. The first letterhead includes the motto 'to strengthen Judaism and to improve kashruth' [sic].

An undated early draft constitution for the organisation includes clauses to establish separate facilities for ritual baths, marriages, burials and commercial food supervision. This wish list indicates the influence of the Heilpern family (especially Hershel and later his sons Godol and Chaim) but should not be taken as an agreed plan for an inevitable austritt gemeinde. Apart from kashrus, the list contains facilities that could and were operated by fully integrated constituent synagogues of the Shechita Board. The Reichs and many other MH leaders were never totally convinced that absolute austritt was necessary and much preferred to reach agreement with the Shechita Board and other mainstream orthodox institutions over kashrus. According to the draft constitution, membership is to be restricted to those who are 'shomrei Shabbos and mitzvos' (i.e. fully observant). Another clause states the organisation 'shall not affiliate to any body not conforming to the principles of the community,' presumably aimed as a warning shot across the bows of the Jewish Communal Council of Manchester \& Salford and the Board of Deputies of British Jews. ${ }^{102}$ In other words, the new organisation would not include people it regarded as tainted with reformist tendencies or orthodox but liable to make 'unnecessary' compromises with British society and modernity. In fact, the founders appear to have agreed to follow the philosophy of Yaakov Dovid Wilowsky, the Slutzker Rov, who had famously declared on a visit to New York in 1900 that virtually all western Jews were sinners for abandoning authentic orthodoxy. The Slutzker Rov, speaking in the regulation rabbinical style,' took the occasion to announce publicly that 'anyone who emigrated to America was a sinner, since, in America, the Oral Law is trodden under foot. It was not only home that the Jews left behind in Europe, he said, it was their Torah, their

\footnotetext{
${ }^{102}$ Typescript of the draft in the possession of the author.
} 
Talmud, their yeshivot - in a word, their Yiddishkeit, their entire Jewish way of life. $^{, 103}$

The inaugural $\mathrm{MH}$ executive committee, as the founders resolved themselves to be, agreed to fund the organisation's activities by collecting subscriptions of $6 \mathrm{~d}$ or $1 \mathrm{~s}$ a week from its small but slowly increasing membership. ${ }^{104}$ The 'questionable procedures and personnel' of mainstream orthodoxy were unacceptable to the original MH members, several of whom had qualified as religious slaughterers in eastern Europe although nearly all now worked in the local cotton textile industry. An important story is that of Mordekhai Zev (Marcus Wolf) Dresdner, a Belzer hassid born in 1882 in Brody. Although he was a qualified slaughterer he had some difficulty making an adequate living. He and his wife left Brody travelled via Hamburg and Hull to Manchester in $1910 .^{105}$ Apparently they came to Manchester because Mrs Dresdner had relatives in the city, the Grosskopfs, who were cotton textile agents. Wolf Dresdner initially went into textiles with the Grosskopfs and lived in Choir Street, Lower Broughton then in Wellington Street East, Higher Broughton. ${ }^{106}$

The Polish shul became the first correspondence address for the new $\mathrm{MH}$ organisation. ${ }^{107}$ Within a few weeks the new group received support from other orthodox immigrants including several additional hassidic members of the (New) Romanian Synagogue and the Lubavitcher hassidim Wolf Jaffe and Mottle Jaffe, both successful businessmen and stalwarts of the Lubavitch shteibl, the 'Hayshop Shul' and later of the second Lubavitch synagogue, New Kehal Hassidim of Waterloo Road, Hightown. ${ }^{108}$ From the start the organisation intended to be taken seriously. It had large quantities of letterheads printed. Manchester's MH now uses a logo of the two tablets of the Decalogue within a Torah scroll, surmounted by a crown (of Torah),

\footnotetext{
${ }^{103}$ M. Davis, The Emergence of Conservative Judaism: The Historical School in 19th Century America (Philadelphia: The Jewish Publication Society of America, 1963), 316.

${ }^{104}$ Chaim Heilpern interview with Bill Williams, 15 November 2002, Bill Williams Jewish Studies Library, Centre for Jewish Studies, University of Manchester.

${ }^{105}$ The late Rabbi Dr Harry Rabinowitz incorrectly dates the Dresdners entry to the UK as 1939 in his book A World Apart: The story of the Chasidim in Britain (London: Vallentine Mitchell, 1997).

${ }^{106}$ Interview with the late Sholem Dresdner, younger son of Wolf Dresdner, 24 September 2000, in the possession of the author.

${ }^{107}$ Copies of the letterhead in possession of the author.

${ }^{108}$ Wolf Jaffe's sons would all become orthodox community activists even though two of them were also busy doctors. His eldest son Zalman would become President of the MSB and lay leader of the Lubavitch community. Interview with his grandson Rabbi Abraham Jaffe, 15 August 2001, in the possession of the author.
} 
with seven branched candelabra, representing the two Temples to the left and right. Underneath in Hebrew letters is the word 'Manchester' followed by the acronym for 'may G-d protect and preserve it.' The original 1925 letterhead had a logo incorporating a six-pointed star of David rather than a crown but this has since disappeared presumably because of its later Zionist and State of Israel connotations. The founding of an MH Society can now be seen as a major milestone in the gradual fragmentation of orthodoxy in Manchester. The harēdim would come to identify only with Agudas Yisroel and the non-Zionist movement whilst nearly all of the English (modern) orthodox congregations would sympathise with the Mizrachi - the religiousZionist organisation. ${ }^{109}$

The Brody hassidim had to confront an entirely different set of challenges and opponents after they arrived in Manchester. Rather than the well known antiSemitism, envy and intolerance of the gentile Polish peasantry and their aristocratic overlords, the $\mathrm{MH}$ founders would have to grapple with the politics of Jewish identity in their new homeland. Here their main challenge would not come from the generally indifferent, gentile working class amongst whom they would live but from people who regarded them as social and religious inferiors: the acculturated, wealthy patricians of Manchester orthodoxy. Here the main battles would not be between reform and orthodox, nor between Haskalah and rabbinics, nor even between Zionism, socialism and Talmudic tradition (although all these surfaced from time to time) but between the upper middle class merchants and lawyers who controlled the MSB and those whom they regarded as fanatical upstarts. The battle would be for control of the institutions of orthodoxy and the extent to which orthodox Judaism in Manchester should accommodate the demands of the broader British political establishment.

\footnotetext{
${ }^{109}$ See B. Williams, Sir Sidney Hamburger \& Manchester Jewry: Religion, City \& Community (Manchester: Vallentine Mitchell, 1999). Many modern orthodox leaders such as Hamburger also held senior positions in the Manchester branches of the various Zionist organisations.
} 


\section{BIBLIOGRAPHY}

\section{Publications}

G. Bacon, The Politics of Tradition: Agudat Yisrael in Poland, 1916-1939 (Jerusalem: The Hebrew University Magnes Press Ltd., 1996).

G. Bacon, 'Imitation and Rejection: Agudat Yisroel and the Zionist Movement 19121939' in S. Eisenstadt and M. Lissak, eds., Zionism and the Return to History: A Reappraisal (Jerusalem: Yad Ben-Zvi Press, 1999).

C. Bermant, Troubled Eden: an anatomy of British Jewry (London: Vallentine Mitchell, 1970).

E. Black, 'A typological study of English Zionists', Jewish Social Studies 9.3 (Indiana, 2003), 20-55.

A. Bromberg, Der Rebbes of Ger (Jerusalem, 1952).

M. Davis, The Emergence of Conservative Judaism: The Historical School in 19th Century America (Philadelphia: The Jewish Publication Society of America, 1963).

T. Ferber, Zikaron L'Dor Akhron [A Memoir of the Last Generation] (London, 1953).

L. Gartner, The Jewish Immigrant in England 1870-1914 (London: Allen and Unwin, 1960).

T. Gasowski, 'Jewish communities in autonomous Galicia' in A. Paluch, ed., The Jews in Poland (Cracow: Jagiellonian University, 1992), 205-221.

P. Goodman, Zionism in England 1899-1949 (London: Zionist Federation of Great Britain, 1949).

L. Jacobs, Helping with inquiries (London: Vallentine Mitchell, 1989).

C. Kadushin, A Short Introduction to Social Networks: A Non-Technical Elementary Primer (New York: Cohen Centre for Modern Jewish Studies, Brandeis University and Graduate Centre City University of New York, 2000).

D. Kranzler, Holocaust hero: the untold story and vignettes of Solomon Schonfeld, an extraordinary British orthodox rabbi who rescued 4,000 during the Holocaust (Jerusalem: KTAV Publishing House, Inc., 2003).

V. Lipman, Social history of the Jews in England 1850-1950 (London: Watts and Co., 1954).

R. Livshin, 'Acculturation of Immigrant Jewish Children 1890-1930' in D. Cesarani, ed., The Making of Modern Anglo-Jewry (Oxford: Blackwell, 1990). 
J. Meltzer, Chaim Weizmann: The Manchester period, prelude to the Balfour declaration (London, 1973).

A. Mittleman, Agudat Israel: The Politics of Torah: The Jewish Political Tradition and the Founding of Agudat Israel (Albany: State University of New York, 1996).

A. Myers, The Jewish Directory for 1874 (London: Philip Valentine, 1874).

H. Rabinowitz, A World Apart: The Story of the Chasidim in Britain (London: Vallentine Mitchell, 1997).

C. Russell and H.S. Lewis, The Jew in London: A study of racial character and present-day conditions (London: T. Fisher Unwin, 1900).

E. Shapiro, 'Modern Orthodoxy in Crisis: A Test Case,' Judaism 51:3 (Summer 2002), 347-362.

I.W. Slotki, Seventy Years of Hebrew Education (Manchester: Manchester Central Board for Hebrew Education, 1950).

B. Williams, The Making of Manchester Jewry 1740-1875 (Manchester: Manchester University Press, 1976).

B. Williams, Sir Sidney Hamburger \& Manchester Jewry: Religion, City \& Community (Manchester: Vallentine Mitchell, 1999).

Z.Y. Wise, The sacred and the profane: conflicting views of nation, nationality and governance in the State of Israel, unpublished MA thesis (University of Salford, 2000).

'Manchester' in Jewish Yearbook (London, 1920 edition).

Kelly's Directory of Manchester \& Salford (Salford Central Library, 1925).

\section{Interviews}

Interview with Rev G. Brodie, 15 August 2001, in the possession of the author.

Interview with L.D. Brunner, 25 September 2003, in the possession of the author.

Interview with Sholem Dresdner, 24 September 2000, in the possession of the author.

Interview with Dayan I. Golditch, Oral Archive at Manchester Jewish Museum, May/June 1978.

Interview with Chaim Heilpern, 21 October 2001, in the possession of the author. 
Chaim Heilpern interview with Bill Williams, 15 November 2002, Bill Williams Jewish Studies Library, Centre for Jewish Studies, University of Manchester.

Interview with Rabbi Abraham Jaffe, 15 August 2001, in the possession of the author.

Interview with Rabbi R. Margulies of Manchester Yeshiva, June 2001, in the possession of the author.

Interview with Isadore Yoffey, 26 March 2006, in the possession of the author.

\section{Archives and Miscellaneous}

L. Reich, 'Chassidim in Manchester', unpublished notes prepared for 'Manchester' in H. Rabinowitz, A World Apart: The Story of the Chasidim in Britain (London: Vallentine Mitchell, 1997). Permission granted.

J.C. Sufrin, Appointment Diaries of Yosef Chaim Sufrin of Manchester (1902-1985) for the years 1914-1985, private collection in the possession of his children.

Rabbi Israel Yoffey Papers, 1926-1935, M648, Manchester Central Library.

Manchester Shechita Board minutes, 1892-1897, in the possession of the author.

Manchester Yeshiva minutes, 1911-1950, in the possession of Rev. Brodie (Yiddish).

Correspondence of the Chief Rabbis Nathan Adler, Hermann Adler, Joseph Hertz, Israel Brodie, Immanuel Jakobovits and Jonathan Sacks, London Metropolitan Archives: ACC/2805 Office of the Chief Rabbi. 